\title{
Effect of fluoride-releasing adhesive systems in control of dental enamel hardness subjected to acid challenge
}

\author{
Efeito de sistemas adesivos com liberação de fluoreto no controle da dureza \\ do esmalte dental submetido ao desafio ácido \\ Efecto de los sistemas adhesivos con liberación de fluoruro en el control de la \\ dureza del esmalte dental sometidos a desafió ácido \\ Henrico Badaoui Strazzi SAHYON ${ }^{1}$ \\ Ana Paula Albuquerque GUEDES ${ }^{2}$ \\ André Gustavo de Lima GODAS ${ }^{2}$ \\ Thaís Yumi Umeda SUZUKI ${ }^{1}$ \\ André Luiz Fraga BRISO ${ }^{2}$ \\ Paulo Henrique DOS SANTOS ${ }^{1}$ \\ ${ }^{1}$ Department of Dental Materials and Prosthodontics, Araçatuba School of Dentistry, \\ São Paulo State University (UNESP), 16015.490 Araçatuba - São Paulo, Brazil \\ ${ }^{2}$ Department of Restorative Dentistry, Araçatuba School of Dentistry, São Paulo State University (UNESP), \\ 16015.490 Araçatuba - São Paulo, Brazil
}

\begin{abstract}
Purpose: To evaluate the effect of $\mathrm{pH}$ cycling with erosive solutions on the Knoop hardness of enamel restored with different fluoride-releasing materials. Methods: Eighteen selected bovine teeth were used and divided into 3 groups ( $\mathrm{n}=6$ ) according to the restorative material used (Single Bond 2, One Up Bond F and Clearfil SE Protect). Three slices of each restored tooth were subjected to erosive $\mathrm{pH}$ cycling in acidic solutions (deionized water, citric acid and hydrochloric acid), with alternate phases of demineralization and remineralization. The microhardness recorded before and after erosive $\mathrm{pH}$ cycling was used to determine changes in the enamel. Results: Acidic solutions were able to change the hardness of enamel. After immersion in citric acid, the enamel restored with Clearfil SE Protect showed lesser mineral loss than the enamel restored with other materials at a distance of $30 \mu \mathrm{m}$. There was an increase in the mineral loss after cycling with hydrochloric acid, compared to deionized water. In the distance of $70 \mu \mathrm{m}$ from adhesive interface, the enamel restored with Single Bond 2 showed greater mineral loss after immersion in citric acid. Conclusions: The fluoride present in Clearfil SE Protect adhesive system was able to protect the dental enamel against erosion process.

Descriptors: Tooth Demineralization; Dental Enamel; Sodium Fluoride.
\end{abstract}

\section{Resumo}

Objetivo: Avaliar o efeito do ciclo de $\mathrm{pH}$ com soluções erosivas na dureza Knoop do esmalte restaurado com diferentes materiais liberadores de flúor. Materiais e Metodo: Dezoito dentes bovinos foram utilizados e divididos em 3 grupos ( $\mathrm{n}=6$ ) de acordo com os materiais restauradores usados (Single Bond 2, One Up Bond F e Clearfil SE Protect). Três fatias de cada dente restaurado foram submetidos ao desafio de $\mathrm{pH}$ erosivo em soluções ácidas (água deionizada, ácido cítrico e ácido clorídrico) com fases alternadas de desmineralização e remineralização. Os dados de microdureza antes e depois da ciclagem de $\mathrm{pH}$ erosiva foram utilizadas para determinar as alterações no esmalte. Resultados: Soluções ácidas foram capazes de alterar a dureza do esmalte. Após a imersão em ácido cítrico, o esmalte restaurado com Clearfil SE Protect apresentou menor perda mineral em relação ao esmalte restaurado com os outros materiais na distância de $30 \mu \mathrm{m}$. Houve um aumento na perda mineral após a ciclagem em ácido clorídrico comparado a água deionizada. Na distância de $70 \mu \mathrm{m}$ da interface adesiva, o esmalte restaurado com Single Bond 2 apresentou maiores valores de perda mineral após a imersão em ácido cítrico. Conclusão: O fluoreto presente no sistema adesivo Clearfil SE Protect foi capaz de proteger o esmalte dentário contra o processo erosivo.

Descritores: Desmineralização do Dente; Esmalte Dentário; Fluoreto de Sódio.

\section{Resumen}

Meta: Evaluar el efecto del pH en el ciclo de soluciones erosiva em Knoop dureza del esmalte restaurada con diferentes materiales de fluoruro de liberación. Materiales y Métodos: Dieciocho dientes bovinos se usaron y se dividieron en 3 grupos $(n=6)$ de acuerdo con los materiales de restauración utilizados (Single Bond 2, One Up Bond F y Clearfil SE Protect). Tres rebanadas de cada diente restaurado se sometieron a desafío erosiva en soluciones de $\mathrm{pH}$ ácido (agua desionizada, ácido cítrico y ácido clorhídrico) con etapas de desmineralización y remineralización alterna. Se utilizaron los datos de microdureza antes y después del ciclismo pH erosiva para determinar el cambio en el esmalte. Resultados: Las soluciones ácidas fueron capaces de cambiar la dureza del esmalte. Después de la inmersión en ácido cítrico, el esmalte restaurada con Clearfil SE Protect mostró menos pérdida de mineral en relación con esmalte restaurado con otros materiales en la distancia de $30 \mu \mathrm{m}$. Hubo un aumento en la pérdida de mineral después de ciclismo en ácido clorhídrico en comparación con agua desionizada. La distancia de la interfaz adhesivo $70 \mu \mathrm{m}$, esmalte restaurada con Single Bond 2 mostró valores más altos pérdida mineral después de la inmersión en ácido cítrico. Conclusión: El fluoruro en Clearfil SE Protect sistema adhesivo fue capaz de proteger el esmalte contra la erosión.

Descriptores: Desmineralización Dental; Esmalte Dental; Fluoruro de Sodio,

\section{INTRODUCTION}

Dissolution of enamel is frequently discussed in the literature owing to its clinical implications. Dental erosion is the loss of tooth structure caused by chemical dissolution from an acidic origin with no bacterial involvement ${ }^{1}$. It is an irreversible process and may have both extrinsic ${ }^{2}$ and intrinsic origins ${ }^{3}$.

Among the extrinsic etiological factors causing dental erosion, the relevant is diet, which may include ingestion of acid food and beverages ${ }^{4}$. Citric acid is the main acid present in acid food and beverages and has high dissolving power of the dental enamel. The intrinsic factors promoting dental erosion are caused mainly by stomach acid in contact with oral cavity due the frequency of vomiting or regurgitation. Gastroesophageal reflux and gastrointestinal diseases allows the loss and demineralization of dental mineralized tissues due of the constant presence of hydrochloric acid from the 
gastric contents into the oral cavity ${ }^{4}$.

Because of the complexity of tooth enamel demineralization, in vitro ${ }^{5}$ and in situ studies ${ }^{6}$ have been performed to enhance the understanding of the process involved in enamel demineralization. Some studies have shown that the enamel remineralization process on eroded teeth is different from that seen on decayed teeth ${ }^{7}$. It is clinically relevant to study the aspects of remineralization of enamel lesions in the early stages of erosion ${ }^{8}$, because softened enamel can undergo remineralization, increasing its mechanical strength ${ }^{9}$.

The use of fluoride-releasing adhesive systems or restorative materials may contribute to the remineralization of the dental substrate ${ }^{10}$. The fluoride released by these materials aids the preservation of the cavity walls by decreasing the risk of marginal microleakage in restorations ${ }^{11}$. Therefore, it is worthwhile to determine whether fluoride could contribute to the remineralization process of erosive lesions in the early stages.

The microhardness test is a laboratory procedure used in the assessment of enamel erosion, and involves indentation of the enamel surface with a diamond probe. It enables the measurement of enamel surface hardness in thin materials, as found in the adhesive interface between enamel and resin composite restorations ${ }^{12}$. It is useful in detecting soft modifications in the enamel surface, which occur in the early stages of erosion.

The present study investigated the effect of erosive $\mathrm{pH}$ cycling with acidic solutions that simulate extrinsic and intrinsic erosion on the microhardness of enamel restored with fluoride-releasing adhesive systems. The null hypotheses tested were as follows: 1) acidic solutions would not cause any significant effect on enamel hardness, and 2) the use of various restorative materials, including materials with fluoride-releasing ability, would not influence the micromechanical properties of dental enamel.

\section{MATHERIAL AND METHODS}

\section{o Specimen Preparation}

The in vitro study was submitted to the Ethical Principles of Animal Experimentation of the Araçatuba School of Dentistry - UNESP (Protocol FOA n ${ }^{\circ} 00567$ 2016). Eighteen fresh bovine teeth were selected and divided into 3 groups according to restorative procedure performed ( $\mathrm{n}=6$ per group) (Figure 1).

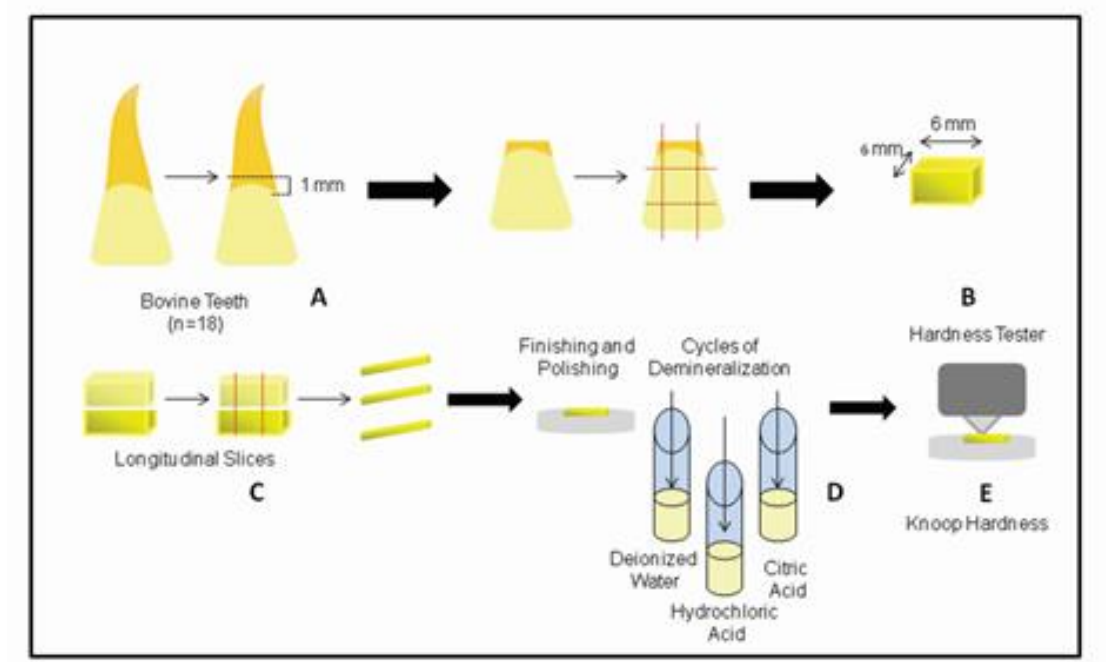

Figure 1: Specimen preparation. A, Removal of root of tooth $1.0 \mathrm{~mm}$ above cementum-enamel junction. B, Obtainment of enamel blocks measuring $6.0 \times 6.0 \mathrm{~mm}$. C, The blocks (enamel-restoration) were cut into three longitudinal slices. $\mathrm{D}$, The demineralization of the slices was performed using $25 \mathrm{ml} 0.3 \%$ citric acid, $25 \mathrm{ml} 0.01 \mathrm{M}$ hydrochloric acid and $25 \mathrm{ml}$ of deionized water. E, Knoop hardness (KHN) measurements with load of $25 \mathrm{~g}$ for $5 \mathrm{~s}$.
The surface of each tooth was manually finished with \#600 grit silicon carbide (Extec Corp, Enfield, CT, USA). The composition of the materials is shown in Table 1.

Table 1 - Materials, manufacturer, composition, and batch number of the materials.

\begin{tabular}{|c|c|c|c|}
\hline Material & Manufacturer & Composition & Batch \\
\hline $\begin{array}{l}\text { Adper Single } \\
\text { Bond } 2\end{array}$ & $\begin{array}{l}\text { 3M Espe, St } \\
\text { Paul, Minn, } \\
\text { USA }\end{array}$ & $\begin{array}{l}\text { Silica nanofiller, BisGMA, HEMA, } \\
\text { dimethacrylates, ethanol, water, } \\
\text { methacrylate functional copolymer of } \\
\text { polyacrylic and polyitaconic acids. }\end{array}$ & N411009BR \\
\hline $\begin{array}{c}\text { Clearfil SE } \\
\text { Protect }\end{array}$ & $\begin{array}{l}\text { Kuraray } \\
\text { Medical Inc, } \\
\text { Kurashiki, } \\
\text { Japan }\end{array}$ & $\begin{array}{l}\text { Primer: water, MDP, MDPB, HEMA, } \\
\text { Hydroponic methacrylate } \\
\text { Bond: MDP, HEMA, Bis-GMA, } \\
\text { Hydroponic dimethacrylate, di- } \\
\text { camphorquinone, N-diethabol-p- } \\
\text { toluidine, silanized colloidal silica. }\end{array}$ & 051509 \\
\hline $\begin{array}{l}\text { One Up } \\
\text { Bond F }\end{array}$ & $\begin{array}{l}\text { Tokuyama, } \\
\text { Dental Corp, } \\
\text { Tokyo, Japan }\end{array}$ & $\begin{array}{l}\text { A) Monomer phosphate (self-etching } \\
\text { monomer), MAC 10, Bis-GMA, TEDMA, } \\
\text { photoinitiators; } \\
\text { B) HEMA, photoinitiators, water and } \\
\text { glass fluor-aluminium silicate. }\end{array}$ & $\begin{array}{l}\text { A) } 077 \\
\text { B) } 567\end{array}$ \\
\hline Filtek Z250 & $\begin{array}{l}\text { 3M Espe, St } \\
\text { Paul, Minn, } \\
\text { USA }\end{array}$ & $\begin{array}{c}\text { Synthetic fillers particles zirconia / silica } \\
\text { having a particle size of } 0.01 \text { to } 3.50 \\
\text { microns. Resin: TEGDMA, UDMA } \\
\text { and Bis-EMA. }\end{array}$ & N306662BR \\
\hline
\end{tabular}

- Group 1: Teeth were etched with $32 \%$ phosphoric acid (Bisco, Inc., Schaumburg, IL, USA) for $15 \mathrm{~s}$, followed by washing with deionized water and gentle air-jet drying. Two consecutive layers of Single Bond 2 adhesive system (3M Espe Dental Products, St. Paul, MN, USA) were applied to the surfaces. The teeth were gently air-dried for solvent evaporation and light-cured with Ultraled light curing unit (Dabi Atlante, Ribeirao Preto, SP, Brazil) for 20 s. A block of Filtek Z250 composite resin (3M ESPE Dental Products, St. Paul, MN, USA) approximately $3 \mathrm{~mm}$ in height was built on the hybridized enamel surface. The composite resin was placed in two increments, each light-cured for 20s.

- Group 2: The enamel surface was treated with the Clearfil SE Protect self-etching adhesive system containing fluoride and an antibacterial agent (Kuraray Medical Inc., Kurashiki, Japan). Initially the primer was applied for $20 \mathrm{~s}$ and gently air-dried for $5 \mathrm{~s}$. The bonding agent was applied, gently air-dried for $5 \mathrm{~s}$, and then light-cured for $10 \mathrm{~s}$. A block of Filtek Z250 composite resin was built as previously described for Group 1.

- Group 3: Teeth were treated with the One Up Bond F self-etching fluoride-containing adhesive system (Tokuyama Dental Corp, Tokyo, Japan). The mixture of product A with product $\mathrm{B}$ was applied to the teeth and then light-cured for 10 s. A block of Filtek Z250 composite resin was built as previously described for Group 1.

After $24 \mathrm{~h}$, three longitudinal slices of each restored tooth were obtained by using a water-cooled low-speed diamond saw (Isomet 2000; Buehler Ltd., Aurora, OH, USA). The slices were embedded in acrylic resin (Clássico, São Paulo, SP, Brazil), manually finished with \#600, 800, and 1200 grit silicon carbide and polished with diamond pastes $(6,3,1$, and $0.25 \mu \mathrm{m})$ for a period of $4 \mathrm{~min}$ for each step. The samples were cleaned in an ultrasonic vat (model 2210, Branson Ultrasonic Corp., Danbury CT, EUA) with deionized water for $5 \mathrm{~min}$ between the steps and at the end of the process.

\section{o Sample Selection}

Initially, fifty healthy incisors from young cattle were obtained from a local abattoir. The teeth were cleaned and stored in $0.1 \%$ thymol solution. Later, 6 x $6 \mathrm{~mm}$ experimental units (enamel/dentin blocs) were obtained from the middle of the bucal surface of these teeth. These blocs were subjected to an initial reading of hardness using HMV 2000 microhardness tester (Shimadzu Corp., Kyoto, Japan). After obtaining the values of hardness (between 325 - 385 
KHN), the median of the hole sample was calculated. Then, eighteen specimens presenting hardness values closer to the median with a tolerance level of $10 \%$ were selected.

\section{o Determination of Knoop Hardness}

The enamel microhardness was tested using the HMV 2000 microhardness tester (Shimadzu Corp., Kyoto, Japan) at 30 and $70 \mu \mathrm{m}$ from the restorative interface. Five indentations were made using a load of $25 \mathrm{~g}$ for $5 \mathrm{~s}$. The Knoop hardness values were assessed by CAMs program WIN (NewAge, Pennsylvania, USA).

$\circ$ Erosive pH Cycling

Each slice of tooth was subject to a determined cycle of demineralization/remineralization. Demineralization was performed individually in three different solutions: 1) $25 \mathrm{ml}$ of citric acid $0.3 \%$ (w/v) at $\mathrm{pH} 3.25$ (adjusted with sodium hydroxide) under continuous stirring $(70 \mathrm{rpm})$ at room temperature $^{8}$;2) $25 \mathrm{ml}$ of $0.01 \mathrm{M}$ hydrochloric acid at $\mathrm{pH} 2.0$ (adjusted with sodium hydroxide) under continuous stirring $(70 \mathrm{rpm})$ at room temperature ${ }^{13}$; and 3$)$ deionized water used as a control. The slices were subjected to alternate periods of demineralization (every $30 \mathrm{~s}$ ) and remineralization (every hour) until a total of $150 \mathrm{~s}$ of demineralization was completed (beginning and ending with demineralization) ${ }^{8}$. Remineralization was performed at $37^{\circ} \mathrm{C}$ with the remineralizing solution $(250 \mathrm{ml})$ continuously stirred with staticand samples. The remineralizing solution comprised $0.7 \mathrm{~mol} / \mathrm{L} \mathrm{CaCl}$, $4.0 \mathrm{~mol} / 1 \mathrm{KH}_{2} \mathrm{PO}_{4}, 0.2 \mathrm{~mol} / \mathrm{l} \mathrm{MgCl}_{2}$, and $20.0 \mathrm{~mol} / \mathrm{l} \mathrm{HEPES}$ at $\mathrm{pH} 7.0$ and $0.125 \mathrm{Ca} / \mathrm{P}$ mole ratio ${ }^{8}$.

After erosive $\mathrm{pH}$ cycling, the Knoop microhardness measurements were performed in the same manner as described above.

\section{- Statistical Analysis}

The Kruskal-Wallis test was used for comparison of microhardness among the groups $(\mathrm{p}<0.05)$ and Friedman test for comparison between initial and final microhardness values $(p<0.05)$ at distances of 30 and $70 \mu \mathrm{m}$ from the adhesive interface.

\section{RESULTS}

As shown in Table 2 and Figure 2, at a distance of 30 $\mu \mathrm{m}$ from the adhesive interface, the enamel restored with Clearfil SE Protect had the maximum mineral loss after cycling with deionized water, significantly greater than that of the enamel restored with One Up Bond $\mathrm{F}$ and Adper Single Bond $2(\mathrm{p}=0.001)$. After storage in hydrochloric acid, there was no difference in the microhardness of the enamel restored with all the materials $(p>0.05)$. After immersion in citric acid, the enamel restored with Clearfil SE Protect showed lesser mineral loss than the enamel restored with other materials $(p<0.05)$. There was an increase in the mineral loss after cycling with hydrochloric acid, compared to deionized water $(\mathrm{p}<0.05)$.

Table 2 - Difference of Knoop microhardness values $(\triangle \mathrm{KHN} \pm$ standard deviation) of the enamel at a distance of $30 \mu \mathrm{m}$ from bonded interfaces.

\begin{tabular}{cccc}
\hline & Deionized water & $\begin{array}{c}\text { Hydrochloric } \\
\text { Acid }\end{array}$ & Citric Acid \\
\hline $\begin{array}{c}\text { Adper Single } \\
\text { Bond 2 }\end{array}$ & $25.9 \pm 18.0 \mathrm{~B} \mathrm{~b}$ & $116.0 \pm 16.4 \mathrm{~A} \mathrm{a}$ & $115.4 \pm 12.4 \mathrm{~A} \mathrm{ab}$ \\
\hline One Up Bond F & $27.8 \pm 23.9 \mathrm{~B} \mathrm{~b}$ & $149.2 \pm 44.9 \mathrm{~A} \mathrm{a}$ & $111.1 \pm 12.8 \mathrm{~A} \mathrm{ab}$ \\
\hline $\begin{array}{c}\text { Clearfil SE } \\
\text { Protect }\end{array}$ & $41.8 \pm 28.8 \mathrm{~A} \mathrm{~b}$ & $113.1 \pm 48.7 \mathrm{~A} \mathrm{a}$ & $96.7 \pm 25.6 \mathrm{~B} \mathrm{ab}$ \\
$\begin{array}{l}\text { * Mean values followed by uppercase letters in column and lowercase in the line show a statistically } \\
\text { significant difference (5\%). }\end{array}$ & &
\end{tabular}

Table 3 and Figure 3 show that, in the distance of 70 $\mu \mathrm{m}$ from adhesive interface, the enamel restored with Single Bond 2 showed greater mineral loss after immersion in citric acid solution compared to enamel restored with Clearfil SE Protect and One Up Bond F ( $p=0.01)$. There was no difference among the adhesive systems in the other solutions analyzed ( $p>0.05)$. In general, the storage in deionized water showed less mineral loss compared to hydrochloric and citric acid for all adhesive systems $(\mathrm{p}<$ $0.05)$.

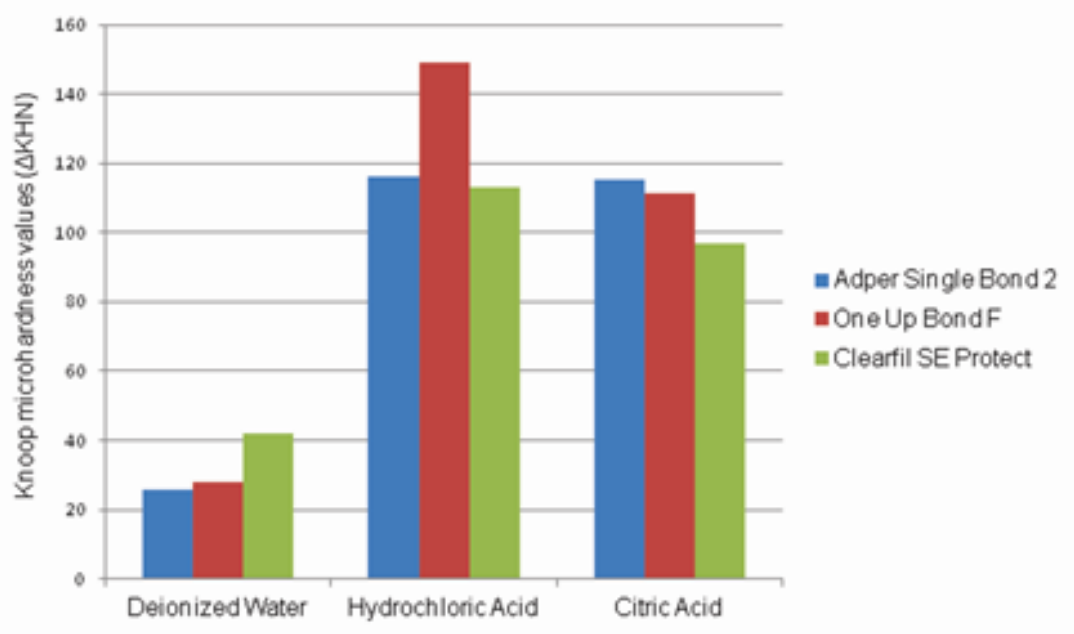

Figure 2: Mean Knoop microhardness values $(\triangle \mathrm{KHN})$ of the enamel at a distance of $30 \mu \mathrm{m}$ from bonded interfaces.

Table 3 - Difference of Knoop microhardness values $(\triangle \mathrm{KHN} \pm$ standard deviation) of the enamel at a distance of $70 \mu \mathrm{m}$ from bonded interfaces.

\begin{tabular}{cccc}
\hline & $\begin{array}{c}\text { Deionized } \\
\text { water }\end{array}$ & $\begin{array}{c}\text { Hydrochloric } \\
\text { Acid }\end{array}$ & Citric Acid \\
\hline Adper Single & $50.3 \pm 13.7 \mathrm{~A} \mathrm{~b}$ & $157.7 \pm 24.2 \mathrm{~A} \mathrm{ab}$ & $171.9 \pm 20.5 \mathrm{~A} \mathrm{a}$ \\
Bond 2 & & & \\
\hline One Up Bond F & $33.9 \pm 26.3 \mathrm{~A} \mathrm{~b}$ & $168.3 \pm 46.4 \mathrm{~A} \mathrm{a}$ & $118.0 \pm 29.7 \mathrm{~B} \mathrm{ab}$ \\
\hline $\begin{array}{c}\text { Clearfil SE } \\
\text { Protect }\end{array}$ & $28.5 \pm 20.9 \mathrm{~A} \mathrm{~b}$ & $118.8 \pm 56.1 \mathrm{~A} \mathrm{a}$ & $104.0 \pm 40.4 \mathrm{~B} \mathrm{ab}$ \\
\hline & & & \\
* Mean values followed by uppercase letters in column and lowercase in the line show a statistically \\
significant difference (5\%).
\end{tabular}

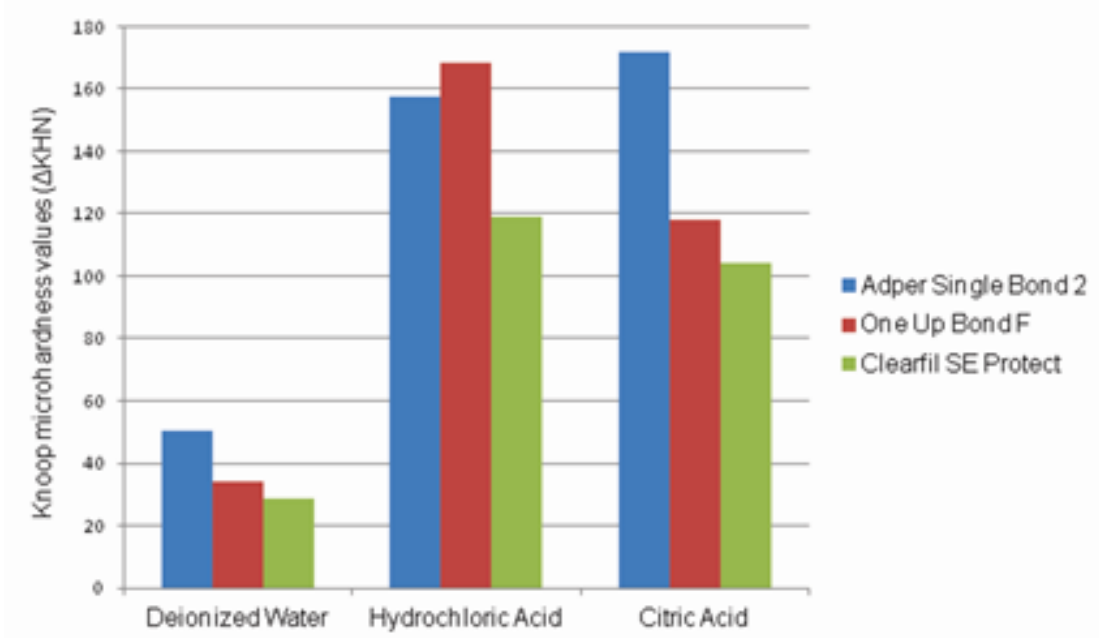

Figure 3: Mean Knoop microhardness values $(\triangle \mathrm{KHN})$ of the enamel at a distance of $70 \mu \mathrm{m}$ from bonded interfaces.

\section{DISCUSSION}

The results demonstrated a significant reduction in enamel microhardness after immersion in hydrochloric and citric acid, as shown in Tables 2 and 3. Badra et al. $(2005)^{14}$ and Francisconi et al. (2008) ${ }^{15}$ reported that composite resins, resin-modified glass ionomer cements, as well as adhesive systems show decreased microhardness when immersed in acidic solutions. The $\mathrm{pH}$, titratable acidity (alkaline volume required to neutralize an acid), and dissociation constant (ease with which $\mathrm{H}^{+}$are released from an acid) are important factors in the chemistry of acids ${ }^{13}$. Titratable acidity and the dissociation constant are considered more relevant than the $\mathrm{pH}$ in the evaluation of the erosive potential of an acidic solution ${ }^{16}$. 
In the present study, hydrochloric acid $(\mathrm{HCl})$ at $\mathrm{pH}$ 2.0 caused statistically similar changes in the enamel microhardness, compared to the changes caused by citric acid. This result is in agreement with those of the studies by Bartlett et al. (2001) $)^{13}$, in which the erosive potential of gastric juice was compared with that of carbonated beverages. These findings are possibly attributable to the low $\mathrm{pH}$ and titratable acidity of these acids, confirming the assumptions that gastric juice has the potential to produce severe erosion patterns in patients with eating disorders and gastroesophageal reflux ${ }^{3,13}$. The current study is an in vitro study, but it emphasizes the important role of saliva in neutralizing acids. It is known that during the consumption of acidic beverages and food, the $\mathrm{pH}$ of the oral environment falls below the critical value, the salivary flow rate increases, and the acid is then diluted by saliva ${ }^{6}$.

The incorporation of fluoride in the composition of restorative materials is directly related to the importance of this component during demineralization and remineralization processes. Additionally, an indirect antibacterial effect prevents secondary caries ${ }^{11}$, by metabolic inhibition of microorganisms. Bromide is inserted into the monomer molecule of an adhesive system owing to its antibacterial effect on microorganisms ${ }^{17}$. Some adhesive systems are incorporated with fluoride and more recently bromide in form of MDPB, such as Clearfil SE Protect. Fluoride adhesive systems have an additional beneficial effect in inhibiting demineralization ${ }^{18}$.

A comparison of the materials at a distance of $30 \mu \mathrm{m}$ from the adhesive interface showed that the enamel restored with One Up Bond $\mathrm{F}$ adhesive system had greater mineral loss than that of the enamel restored with Clearfil SE Protect after immersion in citric acid (Table 2). There was no difference in the mineral loss of the enamel restored with One Up Bond F compared to Adper Single Bond 2 at $30 \mu \mathrm{m}$ from adhesive interface (Table 2) for all acidic solutions. Thus, the mere presence of fluoride in the composition of an adhesive system does not ensure the capacity to inhibit the demineralization process before an erosive process ${ }^{11}$. How the fluoride is incorporated into the material as well as the mechanism of its release defines the effectiveness of this chemical element in adhesive systems. The Clearfil SE Protect adhesive system has irregular particles of sodium fluoride in the bonding agent ${ }^{19}$. It also has bromide added to the acidic MDP molecule of the primer ${ }^{20}$. The antibacterial activity of this adhesive would be associated with the acidity of the primer ${ }^{20}$, controlling of the development of enamel erosion.

The incorporation of inorganic fluoride such as sodium fluoride into the Clearfil SE Protect adhesive system increases fluoride release after an erosive process ${ }^{19}$. The dispersion of glass or leachable soluble fluoride salts in the monomer allows the diffusion of water-soluble fluoride material into the oral cavity ${ }^{19}$. However, the fluoride is released during the polymerization reaction, followed by a small quantity of fluoride released over time ${ }^{21}$. The influence of bromide was not evaluated because the antibacterial effect only occurs in the presence of microorganisms, which was not simulated in this study.

The enamel restored with One Up Bond F adhesive system showed greater mineral loss, compared with enamel restored with the Clearfil SE Protect adhesive system after immersion in citric acid, at $30 \mu \mathrm{m}$ from the adhesive interface (Table 2). It is speculated that the performance of this material is attributable to the characteristics of the adhesive itself and the type of fluoride incorporated, in this case, fluor-aluminium silicate filler ${ }^{22}$. One Up Bond $F$ is considered a single-step self-etching adhesive, which has characteristics of demineralization (acid), infiltration (primer), and bonding (bond) to dental tissues ${ }^{19}$. This adhesive promotes the formation of a permeable hybrid layer ${ }^{23}$. The single-step self-etching adhesive allows the flow of water through the restorative interface, thus compromising the clinical performance of restoration and leading to degradation of the bonding interface ${ }^{24}$. Another factor related to the deficiency of bonding between the enamel and the single-step self-etching adhesive system is the $\mathrm{pH}$ of the adhesive. According to its manufacturer, One Up Bond $\mathrm{F}$ has a $\mathrm{pH}$ of approximately 2.6, which is considered moderate. Therefore, it may not adequately etch the enamel surface ${ }^{19}$, resulting in short resin tags, influencing the restorative procedure.

The Single Bond 2 total-etch adhesive system has a higher infiltration of monomers between the enamel prisms $^{19}$. It occurs by phosphoric acid etching, which has a $\mathrm{pH}$ of approximately 0.7 , allowing mineral removal. This facilitates the infiltration of monomers, resulting in a thicker hybrid layer ${ }^{25}$. The total-etch technique demineralizes the enamel and dentin at a depth of 3-7 $\mu \mathrm{m}^{26}$. Despite the fact that the fluoride released from adhesive material could control demineralization and its ability to prevent secondary caries and erosive lesions, further investigations are necessary to evaluate the effect of other degradation processes, using methodologies with smaller loads and less distances of the restorative interface. Their real effectiveness in a clinical setting is still questionable, since few in situ studies are found. Additionally, the adhesive system alone is not able to completely inhibit demineralization, so the association with other methods must be considered in the prevention of dental erosion.

\section{CONCLUSION}

The acid solutions have the potential to cause enamel erosion modifying the enamel microhardness. The fluoride present in Clearfil SE Protect adhesive system was able to protect the dental enamel against erosion process.

\section{ACKNOWLEDGEMENT}

This study was supported by grants from the CNPQ (Conselho Nacional de Desenvolvimento Científico e Tecnológico, 25608), BRAZIL.

\section{REFERENCES}

1. Kim IH, Son JS, Min BK, Min BK, Kim YK, Kim KH, et al. A simple, sensitive and non-destructive technique for characterizing bovine dental enamel erosion: attenuated total reflection Fourier transforms infrared spectroscopy. Int J Oral Scie. 2016; 8:54-60.

2. Struzycka I, Rusyan E, Boquslawska-Kapala A. Tooth erosion- a multisciplinary approach. Pol Merkur Lekarski. 2016;40:79-83.

3. Kanzow P, Wegehaupt FJ, Attin T, Wiegand A. Etiology and pathogenesis of dental erosion. Quintessence Int. 2016;47 275-8.

4. Guedes APA, Moda MD, Suzuki TYU, Godas AGL, Sundfeld RH, Briso ALF, et al. Effect of fluoridereleasing adhesive systems on the mechanical properties of eroded dentin. Braz Dent J.2016; 27:153-9.

5. Kumar Y, Lohar J, Bhat S, Bhati M, Gandhi A, Mehta A. Comparative evaluation of demineralization of radicular dentin with $17 \%$ ethylenediaminetetraacetic acid, $10 \%$ citric acid, and MTAD at different time 
intervals: An in vitro study. J Int Soc Prev Community Dent.2016; 6 :44-8.

6. Conceição JM, Delbem AC, Danelon M, da Camara DM, Wiegand A, Pessan JP. Fluoride gel supplemented with sodium hemametaphosphate reduces enamel erosive wear in situ. J Dent. 2015; 43:1255-60.

7. Lippert F, Parker DM, Jandt KD. Susceptibility of deciduous and permanent enamel to dietary acid-induced erosion studied with atomic force microscopy nanoindentation. Eur J Oral Sci. 2004; 112:61-6.

8. Lippert F, Parker DM, Jandt KD. In vitro demineralization/remineralization cycles at human tooth enamel surfaces investigated by AFM and nanoindentation. J Colloid Interf Sci. 2004; 2:442-8.

9. Austin RS, Giusca CL, Macaulay G, Moazzez R, Bartlett DW. Confocal laser scanning microscopy and area-scale analysis used to quantify enamel surface textural changes from citric acid demineralization and salivary remineralization in vitro. Dent Mater. 2016;32:278-84.

10. Kirsten GA, Takahashi MK, Rached RN, Giannini M, Souza EM. Microhardness of dentin underneath fluoride-releasing adhesive systems subjected to cariogenic challenge and fluoride therapy. J Dent. 2010; 38:460-8.

11. Borges AB, Scaramucci T, Lippert F, Zero DT, Hara AT. Erosion protection by calclium lactate/sodium fluoride rinses under different salivary flows in vitro. Caries Res. 2014;48:193-9.

12. Barbour ME, Finke M, Parker DM, Hughes JA, Alenn GC, Addy M. The relationship between enamel softening and erosion caused by soft drinks at a range of temperatures. J Dent. 2006; 34:207-13.

13. Bartlett DW, Coward PY. Comparison of the erosive potential of gastric juice and carbonated drink in vitro. $\mathrm{J}$ Oral Rehabil. 2001; 28:1045-7.

14. Badra VV, Faraoni JJ, Ramos RP, Palma-Dibb RG: Influence of different beverages on the microhardness and surface roughness of resin composites. Oper Dent. 2005; 30:213-9.

15. Francisconi LF, Honório HM, Rios DAC, Magalhães AC, Machado MA, Buzalaf MA. Effect of erosive $\mathrm{pH}$ cycling on different restorative materials and on enamel restored with these materials. Oper Dent. 2008; 33:2038.

16. Featherstone JD, Lussi A. Understanding the chemistry of dental erosion. Monogr Oral Sci. 2006;20: 66-76.

17. Imazato S, Ebi N, Takahashi Y, Kaneko T, Ebisu S, Russell RRB. Antibacterial activity of bactericideimmobilized filler for resin-based restoratives. Biomaterials. 2003; 24: 3605-9.

18. Itthagarun A, King NM, Wefel JS, Tay FR, Pashley DH. The effect of fluoridated and non-fluorited rewetting on in vitro recurrent caries. J Dent. 2001; 29: 255-73.

19. Pinto CF, Paes-Leme AF, Ambrosano GM, Giannini M. In vitro secondary caries inhibition by adhesive systems in enamel around composite restorations. Oper Dent. 2010; 35:345-52.

20. Imazato S, Kuramoto A, Takahashi Y, Ebisu S, Peters MC. In vitro antibacterial effects of the dentin primer of Clearfil Protect Bond. Dent Mater. 2006; 22: 527-32.

21. Wiegand A, Buchalla W, Attin T. Review on fluoridereleasing restorative materials - fluoride release and uptake characteristics, antibacterial activity and influence on caries formation. Dent Mater. 2007; 23: 343-62.

22. Hara AT, Queiroz CS, Giannini M, Serra MC, Cury JA Fluoride release and secondary caries inhibition by adhesive systems on root dentin. Eur J Oral Sci. 2005; 113: 245-50.

23. Koshiro K, Sidhu SK, Inoue S, Ikeda T, Sano H. New concept of resin-dentin interfacial adhesion: the nano interaction zone. J Biomed Mater Res B Appl Biomater. 2006; 77:401-8.

24. Tay FR, Lai CNS, Chersoni S, Pashley DH, Mak YF, Suppa $\mathrm{P}$, et al. Osmotic blistering in enamel bonded with one-step self-etch adhesives. J Dent Res. 2004; 83:2905.

25. Perdigão J, Geraldeli S. Bonding characteristics of selfetching adhesives to intact versus prepared enamel. J Esthet Restor Dent. 2003; 15:32-41.

26. Hannig $M$, Bock $H$, Bott $B$, Hoth-Hannig W. Intercrystallite nano retention of self-etching adhesives at enamel imaged by transmission electron microscopy. Eur J Oral Sci. 2002; 110: 464-70.

\section{CONFLICTS OF INTERESTS}

The authors declare no conflicts of interests.

\section{CORRESPONDING AUTHOR}

Paulo Henrique dos Santos

paulosantos@foa.unesp.br

Received 31/03/2017 Accepted 02/05/2017 